\title{
Analysis of the Effectiveness of Schools (a Study At State Junior High Schools In Medan, Indonesia)
}

\author{
Indra Prasetia \\ Lecturer in Muhammadiyah University of North Sumatra and Doctorate Student in Educational Management \\ Department, State University of Medan, Indonesia
}

\begin{abstract}
The study aims to describe and examine the effectiveness of school at school and class level in Medan's junior high schools. In this study, 13 junior high schools were examined which include 7 nationallystandardized junior high schools and 6 independently-fostered Junior High Schools. A total of 275 teachers selected as samples of both types of junior high schools. This study conducted by using mixed methods design, embedded concurrent technique, quantitative as the primary method and qualitative as the secondary method which plays a supporting role in the research findings. The data collected from a survey which employed opened and closed instrument was in one phase of the study. In general, the result shows that nationally-standardized junior high schools are more effective at both the school and grade level compared to independently-fostered junior high schools in Medan.
\end{abstract}

Keywords:School Effectiveness, Process in School and Class Level

\section{INTRODUCTION}

Various studies suggest that the schools in Indonesia have many weaknesses. On one side, most schools usually equipped with a variety of resources, but on the other hand, schools have obstacles in terms of management capabilities. The paradigm of school-based management in an era of the decentralized system of education also demonstrates likewise. World Bank mentioned that the school expansion in Indonesia has not been producing graduates with the knowledge and expertise needed to build a strong society and a competitive economy in the future yet. Creemer's research, from September 1996 to September 1997 in the "Primary Education Quality Improvement Project (PEQIP)" which was a program aiming to improve the quality of schools in Indonesia, found out many weaknesses of the school were due to the poor ability of those principals and supervisors for not being able to statistically improve the quality of school management which also caused by a poor personnel management, institution financial planning, teaching and learning management, evaluation and monitoring, and entrepreneurship. In this study, the effectiveness of school becomes the most important issues in ensuring the achievement of national educational goals.

Furthermore, in today's global context, the index of educational development in Indonesia is still below the rank of some countries such as Malaysia and Thailand. Data taken from Education for All (EFA) Global Monitoring Report in 2011 published by UNESCO suggested that Indonesian educational development index ranked the 69th out of 127 countries in the world. This publication clearly proved that the development of education in Indonesia has not been able to improve the quality of Indonesian human resources nationally. As an addition, the Central Statistics Agency (BPS) in August 2011 also showed that $49.4 \%$ of Indonesian workers only have an educational background equal to Elementary School. Those data, again, proved that the quality of Indonesian workforce is still far behind. This condition is also worsened by the quality of the academic competitiveness of Indonesian students which is, again, still below the average global achievement. Survey from Organization for Economic Co-operation and Development (OECD), an organization for cooperation and economy development, comparing students aged 15 years (junior high school students) from various countries in the areas of literacy, math, and science shows that the average Indonesian students' achievement in 2006-2011 was very low. Of the 68 countries measured, Indonesian students' achievement is below the minimum scale and thus, listed in the relegation zone along with several other under-developed countries.

The low quality of schools in Indonesia, according to the author is due to the practice of schools today which still applying the success criteria based on academic results alone (output oriented), apart from the success of the process and activities (managerial or administrative process and activities) which lead to a poor schools' internal and external efficiency and effectiveness. This problem then, in turn, further affect schools' output in general. Schools that are focusing on output are very likely to have some judgment inaccuracies if it is associated with a system that happened in school. Therefore, the process will run well if the system applied is effective in the first place. In a study of various organizational theory, Gibson. et. al (2009) suggested that the effectiveness is one of the determining factors of the success of the organization. Therefore, the effectiveness of 
the school is very important to be studied and researched. Sallis (1993) said that school effectiveness is closely related to the quality of output of the school. Grusky (1998) similarly agreed upon the idea that the effectiveness of the school is basically the process of producing the products or outputs, characterized by school graduates who have the ability, skill, and competitiveness.

Experiences in many countries show the study of school's effectiveness has been very helpful in solving the problems of education in relation to improving the quality of education itself in general. A number of important research on the effectiveness of schools actually have helped to explain a lot about the importance of school's effectiveness in improving the quality of education. A number of important research on the effectiveness of the school began to emerge in the late 1970s to the present sensitized the significant influence of the school on students' achievement. Various research on school effectiveness conducted by Edmond (1979); Sammons (1995); Hawley and Rolly (2007) found out that schools that are run effectively demonstrate a significant improvement on students' achievement. In its development, the problem of educational resources has also received increasing attention from researchers, especially to those who consider the input of the school as the school effectiveness' factor (Card and Krueger, 1992). Hedges (1994) examined the effect of input resources and pupil expenditure on students' achievement. Furthermore, research by Ferguson (1991) showed the influence of teachers' qualification has some significant variables with students' achievement.

Departing from this issue, the author is very interested and willing to perform an analysis of the extent of the effectiveness of schools, especially secondary schools in Medan. The author feels confident that the nationwide educational downturn is due to processes that occur in schools which suggest a lack of effectiveness in supporting the expected achievement of the learning.

\section{LIMITATIONS, RESEARCH PROBLEM AND PUSPOSES}

Problem definition and research focus on effectiveness at the level of school and grade level where this study will be focusing on are: (1) leadership of the principals, (2) schools environment, (3) the academic norms, (4) teamwork, (5) the development of staffs, (6) the implementation of the curriculum, and (7) the relationship of the school with the community. The level of effectiveness in the classroom will be measured based on: (1) the learning climate, (2) classrooms' climate, (3) learning schedules, and (4) the frequency of evaluations and assignments. Research Questions Are: 1. How high is the level of effectiveness in schools and classes in Junior High School in Medan?2. Are there any differences in the effectiveness of the school among the Junior High Schools in Medan?

This study aims to: (1) describe the effectiveness of the process at the school and grade level in Junior High School in Medan, and (2) determine the differences in the effectiveness of the school among Junior High Schools in Medan.

\section{RESEARCH DESIGN}

This mixture research's design employs embedded technique whose design is presented in table 1 below.

Table 1. Mixed Method Research Design "Concurrent Embedded"

\begin{tabular}{l|l|l|l}
\hline Type of Layout & Implementation & Priority & Integration \\
\hline Concurrent Embbeded & $\begin{array}{l}\text { Analysis of } \\
\text { quantitative and } \\
\text { qualitative data }\end{array}$ & $\begin{array}{l}\text { Quantitative as } \\
\text { primary method and } \\
\text { qualitative as } \\
\text { secondary method }\end{array}$ & $\begin{array}{l}\text { Analysis phase/ } \\
\text { discussion }\end{array}$ \\
\hline
\end{tabular}

\section{RESEARCH SAMPLES AND INSTRUMENT}

Proportionally selected from 487 teachers in state Junior High School in the city. As many as 161 teachers in Junior High School with national standards, and the remaining 114 teachers in independentlyfostered Junior High School.

The data were collected in this study by using a survey method. Instruments used in the form of closed questions (closed-ended questions) and open questions (open- ended questions). Options or answers for closed questions used a graduated scale or rating scale (scale is 1 to 5), with a choice of $1=$ very poor, $2=$ Low, $3=$ Pretty, $4=$ High, and $5=$ Very high. The open questions were provided with a number of questions in the form of an open response.

\section{RESEARCH RESULT}

\section{V.1 Quantitative Data}

Quantitative and qualitative research data analysis is taken from the responses given by the research respondents in the questionnaires. Quantitatively the respondents assess the effectiveness of the process at the 
school level in the nationally-standardized Junior High School as follows: (1) leadership quality of the headmasters reached $86.54 \%$, (2) a comfortable and orderly school environment reached $81.86 \%$ ( 3) academic norms reached $85.09 \%$ (4) teamwork reached $86.58 \%$ (5) the development of the staff reached $85.65 \%(6)$ the implementation of the curriculum reached $84.10 \%$ (7) the relationship with the school community reached $84.45 \%$.Based on this data, It is concluded that the process at school level from the aspects of principals' leadership, school environment, norms of academic, staffs' development, teamwork, implementation of the curriculum, and school's relationships with parents has been supporting the process of achieving the goals of education and learning in school.

The results of data analysis on independently-fostered junior high schools, on the other hand, shows a slightly different results which is presented as follows: (1) principals' leadership reached $78.36 \%$ (2) the school environment reached $80.65 \%$, (3) the academic norm reached $77.76 \%$ (4) teamwork reached $75.50 \%(5)$ the development of the staffs reached $85.05 \%$ (6) the curriculum implementation reached $83.75 \%$ and (7) schoolcommunity reached $70.57 \%$. It is concluded that the process at the school level in the independently-fostered junior high schools has not been fully effective in supporting the process of achieving the goals of education and learning in schools. This conclusion is based on the evidence on schools' environment, staff development, and curriculum implementation aspects while aspects that still supports the effectiveness of the schools are leadership among principals, academic norms, teamwork, and school-community relationship.

Table 2. Effectiveness value at school level in nationally-standardized and independently-fostered In Junior High Schools

\begin{tabular}{|c|c|c|c|c|c|c|c|c|c|}
\hline \multirow[b]{2}{*}{$\begin{array}{l}\mathbf{N} \\
\mathbf{o}\end{array}$} & \multirow[b]{2}{*}{ Dimension } & \multicolumn{4}{|c|}{ SMP Negeri SSN } & \multicolumn{4}{|c|}{ SMP Negeri SPM } \\
\hline & & $\begin{array}{l}\text { Total } \\
\text { Score } \\
\text { (a) }\end{array}$ & $\begin{array}{l}\text { Scor } \\
\text { e } \\
\text { Crite } \\
\text { rium } \\
\text { (b) }\end{array}$ & $\begin{array}{l}\text { Score } \\
:(\text { a) : } \\
\text { (b) } x \\
100 \%\end{array}$ & $\begin{array}{l}\text { Explan } \\
\text { a-tion }\end{array}$ & $\begin{array}{l}\text { Tota } \\
\text { l } \\
\text { Scor } \\
\text { e } \\
\text { (a) }\end{array}$ & $\begin{array}{l}\text { Scor } \\
\text { e } \\
\text { Crit } \\
\text { eriu } \\
\text { m } \\
\text { (b) }\end{array}$ & $\begin{array}{l}\text { Score } \\
:(\text { a) : } \\
\text { (b) } x \\
100 \%\end{array}$ & $\begin{array}{l}\text { explanati } \\
\text { on }\end{array}$ \\
\hline $\begin{array}{c}(1 \\
)\end{array}$ & (2) & (3) & (4) & (5) & (6) & (7) & (8) & (9) & (10) \\
\hline 1 & $\begin{array}{l}\text { Principal's } \\
\text { Leadership }\end{array}$ & 4.180 & 4.830 & $\begin{array}{c}86,54 \\
\% \\
\end{array}$ & $\begin{array}{c}\text { Effectiv } \\
\mathrm{e}\end{array}$ & $\begin{array}{c}2.68 \\
0\end{array}$ & $\begin{array}{c}3.42 \\
0 \\
\end{array}$ & $\begin{array}{c}78,36 \\
\% \\
\end{array}$ & $\begin{array}{c}\text { Effective } \\
\text { enough }\end{array}$ \\
\hline 2 & $\begin{array}{l}\text { Comfortable } \\
\text { and orderly } \\
\text { school } \\
\text { environment }\end{array}$ & 2.636 & 3.220 & $\begin{array}{c}81,86 \\
\%\end{array}$ & $\begin{array}{c}\text { Effectiv } \\
\text { e }\end{array}$ & $\begin{array}{c}1.83 \\
9\end{array}$ & $\begin{array}{c}2.28 \\
0\end{array}$ & $\begin{array}{c}80,65 \\
\%\end{array}$ & Effective \\
\hline 3 & $\begin{array}{l}\text { Academic } \\
\text { norms }\end{array}$ & 2.740 & 3.220 & $\begin{array}{c}85,09 \\
\%\end{array}$ & $\begin{array}{c}\text { Effectiv } \\
\mathrm{e}\end{array}$ & $\begin{array}{c}1.77 \\
3\end{array}$ & $\begin{array}{c}2.28 \\
0\end{array}$ & $\begin{array}{c}77,76 \\
\%\end{array}$ & $\begin{array}{c}\text { Effective } \\
\text { enough }\end{array}$ \\
\hline 4 & Teamwork & 2.788 & 3.220 & $\begin{array}{c}86,58 \\
\%\end{array}$ & $\begin{array}{c}\text { Effectiv } \\
\mathrm{e}\end{array}$ & $\begin{array}{c}1.76 \\
7\end{array}$ & $\begin{array}{c}2.28 \\
0\end{array}$ & $\begin{array}{c}77,50 \\
\%\end{array}$ & $\begin{array}{c}\text { Effective } \\
\text { enough }\end{array}$ \\
\hline 5 & $\begin{array}{c}\text { Staffs' } \\
\text { Developme } \\
\text { nt }\end{array}$ & 2.758 & 3.220 & $\begin{array}{c}85,65 \\
\%\end{array}$ & $\begin{array}{c}\text { Effectiv } \\
\text { e }\end{array}$ & $\begin{array}{c}1.71 \\
1\end{array}$ & $\begin{array}{c}2.28 \\
0\end{array}$ & $\begin{array}{c}85,05 \\
\%\end{array}$ & Effective \\
\hline 6 & $\begin{array}{c}\text { Curriculum } \\
\text { Implementat } \\
\text { ion } \\
\end{array}$ & 3.381 & 4.020 & $\begin{array}{c}84,10 \\
\%\end{array}$ & $\begin{array}{c}\text { Effectiv } \\
\text { e }\end{array}$ & $\begin{array}{c}2.10 \\
2\end{array}$ & $\begin{array}{c}2.85 \\
0\end{array}$ & $\begin{array}{c}83,75 \\
\%\end{array}$ & Effective \\
\hline 7 & $\begin{array}{c}\text { School- } \\
\text { Community } \\
\text { Relationship }\end{array}$ & 4.759 & 5.635 & $\begin{array}{c}84,45 \\
\%\end{array}$ & $\begin{array}{c}\text { Effectiv } \\
\text { e }\end{array}$ & $\begin{array}{c}3.06 \\
7\end{array}$ & $\begin{array}{c}3.99 \\
0\end{array}$ & $\begin{array}{c}70,57 \\
\%\end{array}$ & $\begin{array}{c}\text { Not } \\
\text { Effective }\end{array}$ \\
\hline \multicolumn{4}{|c|}{ Overall Average (\%) } & $\begin{array}{c}84,89 \\
\%\end{array}$ & $\begin{array}{c}\text { Effectiv } \\
\mathrm{e}\end{array}$ & & & $\begin{array}{c}79,09 \\
\%\end{array}$ & $\begin{array}{c}\text { Effective } \\
\text { enough }\end{array}$ \\
\hline
\end{tabular}

From the table 2 above, it can be concluded that there are differences in the level of effectiveness of the school in nationally-standardized and independently-fostered Junior High Schools in Medan. Judging from the difference between the overall average value for the criterion of effectiveness aspects in the school level in the two types of school $(84.89 \%-79.23 \%)$, or $5.8 \%$. Graphically, the effectiveness of the school in nationallystandardized and independently-fostered Junior High Schools is described as follows: 




Picture 1: The differences of criterion score at school level between nationally-standardized and independentlyfostered junior high schools

The score for principal's leadership is $8.18 \%(86.54 \%-78.36 \%)$; comfortable and orderly school environment is $4.36 \%(81.86 \%-77.50 \%)$; academic norm $7.33 \%(85.09 \%-77.76 \%)$; teamwork $9.08 \%$ $(86.58 \%-77.50 \%)$; Staffs' development $0.60 \%(85.65 \%-85.05 \%)$; curriculum implementation $0.35 \%(84.10 \%$ - $83.75 \%)$; school-community relationship $13.88 \%(84.45 \%-70.57 \%)$. Based on the difference in scores of each aspect, it is clear that there are differences in effectiveness between nationally-standardized and independently-fostered junior high schools. Below is the summary of the effectiveness of the two types of school:

Table 3: Score Deviation of Process Effectiveness at School Level:

\begin{tabular}{l|l|l}
\hline Number & \multicolumn{1}{|c|}{ Aspect } & \multicolumn{1}{c}{ Deviation (\%) } \\
\hline$(1)$ & $(2)$ & $(3)$ \\
\hline 1 & School-parent relationship & 13.88 \\
\hline 2 & Teamwork & 9.08 \\
\hline 3 & Principals' Leadership & 8.18 \\
\hline 4 & Academic Norm & 7.33 \\
\hline 5 & School Environment & 4.36 \\
\hline 6 & Staffs's Development & 0.60 \\
\hline 7 & Curiculum Implementation & 0.35 \\
\hline
\end{tabular}

Based on Table 3 above, it can be explained that the relationship of the school with the community in nationally-standardized junior high schools is better than the independently-fostered junior high schools which can be seen from the difference in effectiveness score of $13.88 \%$. Teamwork aspect in nationally-standardized junior high school is better than the independently-fostered junior high school by a difference of $9.08 \%$. Principals' leadership aspect in nationally-standardized junior high school is better than independently-fostered junior high school by a margin of $8,18 \%$. Academic norms in nationally-standardized junior high school are better than the independently-fostered junior high school by $7.33 \%$. School environment in nationallystandardized junior high school is again better than independently-fostered junior high school to $4.36 \%$ gap. Meanwhile, the aspects of staffs' development and curriculum implementation are the same. To conclude, the differences occurred in some aspects as explained above suggest that the nationally-standardized junior high school is more effective than independently-fostered junior high school.

Furthermore, the effectiveness of the data analysis process at classroom level showed no difference. The effectiveness of the process at the level of the class can be examined from the score acquisition of the criterion in every aspect of the process at the classroom level. The following table shows the percentage of every aspect of the process in the classroom in both type of school:

Tabel 4 Data Analysis at Class Level

\begin{tabular}{|c|c|c|c|c|c|c|c|c|c|}
\hline \multirow[b]{2}{*}{$\begin{array}{l}\mathbf{N} \\
\mathbf{0}\end{array}$} & \multirow[b]{2}{*}{ Dimension } & \multicolumn{4}{|c|}{$\begin{array}{l}\text { Nationally-standardized junior high } \\
\text { school }\end{array}$} & \multicolumn{4}{|c|}{$\begin{array}{l}\text { Independently-fostered junior high } \\
\text { school }\end{array}$} \\
\hline & & $\begin{array}{l}\text { Total } \\
\text { Score } \\
\text { (a) }\end{array}$ & $\begin{array}{l}\text { Crite } \\
\text { rion } \\
\text { score } \\
\text { (b) }\end{array}$ & $\begin{array}{l}\text { Perce } \\
\text { ntage } \\
: \text { (a) : } \\
\text { (b) } x \\
100 \%\end{array}$ & $\begin{array}{l}\text { Explanatio } \\
\text { n }\end{array}$ & $\begin{array}{l}\text { Tota } \\
\text { l } \\
\text { (a) }\end{array}$ & $\begin{array}{l}\text { Crite } \\
\text { rion } \\
\text { Score } \\
\text { (b) }\end{array}$ & $\begin{array}{l}\text { Perce } \\
\text { ntage } \\
\text { : (a) : } \\
\text { (b) } x \\
100 \%\end{array}$ & $\begin{array}{l}\text { explanatio } \\
\text { n }\end{array}$ \\
\hline
\end{tabular}


Analysis Of The Effectiveness Of Schools

\begin{tabular}{l|l|l|l|l|l|l|l|l|l}
\hline $\begin{array}{l}(1 \\
)\end{array}$ & $(2)$ & $(3)$ & $(5)$ & $(6)$ & $(7)$ & $(8)$ & $(9)$ & $(10)$ \\
\hline 1 & $\begin{array}{l}\text { Teachers' } \\
\text { expectation }\end{array}$ & 6.642 & 8.075 & $\begin{array}{l}82.25 \\
\%\end{array}$ & High & $\begin{array}{l}6.10 \\
8\end{array}$ & 7.750 & $\begin{array}{l}81.81 \\
\%\end{array}$ & High \\
\hline 2 & $\begin{array}{l}\text { Time } \\
\text { management }\end{array}$ & 5.297 & 6.460 & $\begin{array}{l}81.99 \\
\%\end{array}$ & High & $\begin{array}{l}4.39 \\
9\end{array}$ & 6.200 & $\begin{array}{l}70.95 \\
\%\end{array}$ & Low \\
\hline 3 & $\begin{array}{llllll}\text { Classroom } \\
\text { environmnet }\end{array}$ & 10.89 & $\begin{array}{l}12.92 \\
0\end{array}$ & $\begin{array}{l}84.30 \\
\%\end{array}$ & High & $\begin{array}{l}9.66 \\
8\end{array}$ & $\begin{array}{l}12.40 \\
0\end{array}$ & $\begin{array}{l}77.94 \\
\%\end{array}$ & Average \\
\hline 4 & Assessment & 4.178 & 4.845 & $\begin{array}{l}86.23 \\
\%\end{array}$ & Very High & $\begin{array}{l}3.48 \\
9\end{array}$ & 4.650 & $\begin{array}{l}87.03 \\
\%\end{array}$ & Very High \\
& Frequency & & $\begin{array}{l}83.69 \\
\%\end{array}$ & High & & & $\begin{array}{l}80.68 \\
\%\end{array}$ & High \\
\hline
\end{tabular}

Table 4 above explains that the average percentage of the process at the class level in nationallystandardized junior high school is $83.69 \%$. This suggests that the respondents believe that the process in classrooms is effective in creating a conducive climate for both teaching and learning. The effectiveness of the process in the classroom is visible from every aspect of the process measured such as the frequency of assessment in the classroom which is $86.23 \%$, the management of time allotment which is $84.30 \%$, expectations of teachers in the classroom for $82,25 \%$, and classrooms climate by 81.99 .

Furthermore, the average percentage of the process in independently-fostered junior high school is $81.68 \%$. This shows that the respondents think the classroom process has not been fully effective in supporting a conducive learning climate, where some indicator percentages of the process are still below the level criterion grade such as the frequency of assessment which is $87.03 \%, 81.81 \%$ for the expectations of the teachers, $77.98 \%$ for the time allotment management, and $70.95 \%$ for classroom climate.

Based on the data above, it can be concluded that there are differences in the level of effectiveness of the class in nationally-standardized and independently-fostered junior high schools in Medan. Graphically, the level of effectiveness of the process described as follows:

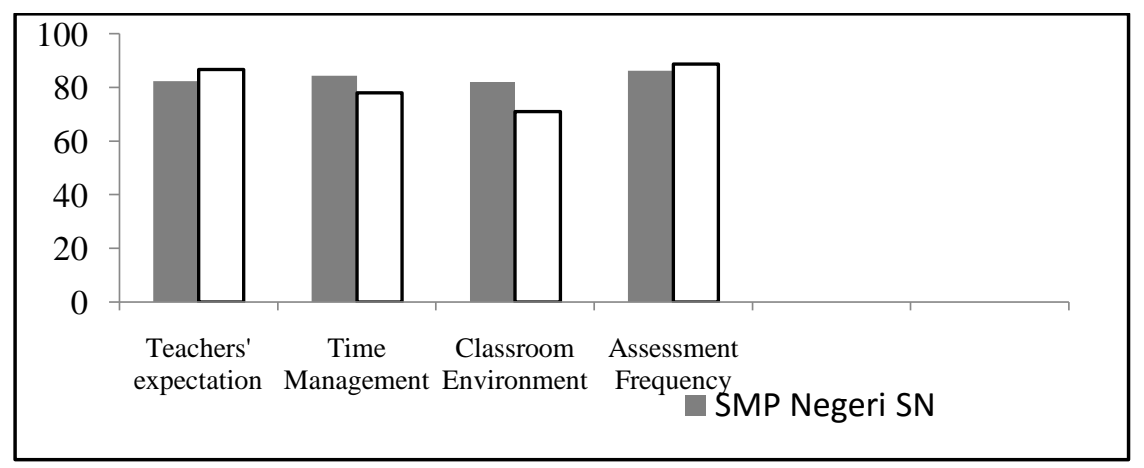

Picture 2: Criterion Score of Effectiveness Process

Based on the analysis above, it is clear that there are some aspects that showed some significant differences in schools' effectiveness at the grade level in nationally-standardized and independently-fostered junior high schools. This can be seen from the difference between each of these aspects, namely $0.44 \%$ for the value of expectation of teachers in the classroom $(82.25 \%-81.81 \%), 11.04 \%$ for the management of the time allotment $(81.99 \%-70.95 \%), 6.36 \%$ for class climate $(84.30 \%-77.94 \%)$, and $0.80 \%$ for the frequency of assessments in the classroom $(86.23 \%-87.03 \%)$.

Table 5. Score and Ranking Process Effectiveness at class Level deviation between nationallystandardized and independently-fostered junior high schools

\begin{tabular}{l|l|l}
\hline Number & \multicolumn{1}{|c}{ Aspect } & \multicolumn{1}{|c}{ Deviation (\%) } \\
\hline$(1)$ & $(2)$ & $(3)$ \\
\hline 1 & Classroom teaching time management & 11,04 \\
\hline 2 & Classroom climate & 6,36 \\
\hline 3 & Teachers expectation in classroom & 0,44 \\
\hline 4 & Assessment frequency & 0,80 \\
\hline
\end{tabular}

Table 5 above shows the time management of classroom teaching in nationally-standardized Junior High School is better than independently-fostered junior high schools which are evident from the difference in effectiveness score, $11.04 \%$. Climate class in nationally-standardized Junior High School is better than independently-fostered junior high schools with the difference in effectiveness score of 6, 36\%. Expectations of 
teachers in the classroom in nationally-standardized Junior High School is slightly better than independentlyfostered junior high schools with a difference of effectiveness score only $0,44 \%$, as well as the frequency assessment by a margin of $0.80 \%$ effectiveness scores.

\section{V.2 QUALITATIVE DATA ANALYSIS}

Results of quantitative data that show that the relationship of the school with the community and teamwork is good which is supported by the qualitative data as well. The respondents argued that the nationallystandardized junior high schools have been able to build an effective partnership with the citizens of the school, especially those with parents of students either individually or in groups. In terms of leadership aspects, principals of the nationally-standardized junior high schools are also very effective to build a positive working climate with all elements of the school, the teacher is able to empower, encourage involvement and participation of the school community in promoting the school. The school principal also managed to build a harmonious relationship so as to create a conducive learning environment and enjoyable for the whole school community. The learning environment is also supported by the enforcement of the norms and rules of the school to all citizens especially the students. The orderly culture has become the character of the school community in Junior High School National Standards, especially those of the students. These are what distinguish the nationallystandardized junior high schools and independently-fostered junior high schools.

Qualitative data on grade level also confirmed it. The respondents thought that the process in the classroom in Junior High School National Standards are more effective when compared with SMP Development Mandiri. According to the respondents, the management of teaching time and classroom climate is very conducive to an effective learning process both in terms of planning, organizing and controlling the time classroom teaching. By managing and utilizing time effectively in the learning process, students' opportunity to acquire and get enough time in teaching becomes high, which in turn gives students the opportunity to acquire the entire curriculum which eventually lead to a very good and learning outcomes. Besides managing time effectively, good classroom climate also supports the creation of a fun learning environment for students by making a class display, assuring the health aspect so as to encourage creativity, motivation, and the convenience of students to study in the classroom. This is what distinguishes the process at grade level between the nationally-standardized junior high schools and independently-fostered junior high schools.

\section{CONCLUSIONS AND SUGGESTIONS}

1. In quantitative terms, the data analysis showed that the process at the school level in nationally-standardized junior high schools supports the process of effective education

2. 2. In quantitative terms, the data analysis showed that the process at the school level in independently-fostered junior high schools is not yet fully effective

3. Statistical measurements show that the process at the school level and the classroom level greatly affect the effectiveness of the school. Effective school has a higher impact on the process at both school and class level

4. The results of qualitative data on effective schools suggest that schools' climate are conducive and schools' citizen participation are high. The quality of schools leadership are also good which can be seen from the high level of trust from school members. Moreover, the relationship and duty behavior between teachers' and the school principals also developed very well, seen from the capacity that empowers and authorizes but still controlling. Characteristics of the humane work environment, collegial and collectively trusting each other increase the participation of teachers and parents to cooperate and work together with the school. In general, an effective school has a characteristic of an open organization that enhances the realization of the achievement of school goals effectively.

5. In an ineffective, the climate is less conducive, school-community relationships and participation is still low, harmonization and collegial cooperation between components have a constraint that is usually caused by the working environment that is not yet well-developed. Tasks and control are high, the relationship between personnel is low, greatly affects the level of satisfaction of teachers about the school. In this case, harmonization of the relationship has a direct impact on the level of participation of teachers, and parents. In addition, the school's limited resources (infrastructure) also affects the quality of the learning process in schools. In general, the ineffective school has the character of a closed organization.

Given the school is an institution of education and learning, the school effectiveness definitely needs to be improved because the issue of school effectiveness is closely related to the performance, satisfaction and achievement and objectives of the school. Therefore, the results of this research will have implications on the following matters:

1. To improve the effectiveness of the school, a conducive school climate needs to be created so that the learning process goes smoothly and the students' and schools' achievements increase 
2. Given the very central role of the principal, the relationship and duties behavior between the management people and subordinates also needs to be created to encourage a healthy work environment

3. Schools need to practice the system of an open organization, leadership is adaptable to the needs and demands of the school and school community so that community trust in the school can also be increased

4. The aspects that have been measured in this can be used as a source and consideration for schools so that the process and work performance in the school and the classroom can be better improved to further increase schools' effectiveness.

\section{REFERENCES}

[1] Achilles. C.M. Student Achieve More in Smaller Classes. Journal Education Leadership. 53. 1996. Pp 7677.

[2] Alma, Harris, (2004) Departmental Effectiveness and Schools Effectiveness : Exploring and Missing Link. Journal for Effective Schools. Vol. 3 No. 1 Idaho State University. ICEE.

[3] Badan Pusat Statistik (2011) Indonesia Dalam Angka. BPS. Jakarta.

[4] Bass, B.M dan Stogdill, R.M (1990). Bass and Stogdill's Handbook of Leadership. $3^{\text {rd }}$ Edition. New York : Free Press.

[5] Bush, T dan Coleman, M. (2000). Leadership and Stratrgic Management and Education. London : A Sage Publications Company.

[6] Card, D., and Krueger, A.B. Does School Qulity Matter ? Returns to Education and the Caracteristics of Public Schools in the United State. In Journal of Political Economy. 100. 1992. Pp 1-40

[7] Creswell, J.W. (2009). Research Desigh : Qualitative, Quantitative, and Mixed Methods Approaches. Third Edition. Sage Publications. California.

[8] Daly, AJ dan Chrispeel, A. (2005). From Problem to Possibility : Leadership for Implementing and Deepening the Processes of Effective Schools. Journal Effective Schools. Vol 4 No.1. Idaho State University.

[9] Education For All (EFA) Global Monitoring Repot 2011.http/www.unesco.org

[10] Edmond, R. Effective Schools for the Urban Poor. Journal Educational Leadership. By Association for Journal Supervision and Curriculum Development. Oktober 1979. Pp 12-24

[11] Ferguson, R.F. Paying for Public Education : New Evidence on How and Why Money Matters. Harvard Journal on Legislation. 28. 1991.Pp 465-498.

[12] Gibson, J.L., Ivancevich, J.M., Donnelly, J.H., dan Konopaske, R. (2009). Organizations : behavior, Structure, Processes. $11^{\text {th }}$ Edition. New York : McGraw-Hill Irwin.

[13] Grusky, Oscar (2008) Managerial Succesion and Organizational Effective. The American Journal of Sociology, Vol. 69, No. 1. (Jul., 1963), pp. 21-31. University of Chicago Press.

[14] Hedges, L.V., Laine, R.D., and Greenwald, R. Does Money Matter? A Meta-Analysis of Studies of the Effect of Diffrential School Input on Student Outcames. Journal Education Researchcer. 23 (3). 1994. Pp 5-14.

[15] Lazotte, L.W. (2011) Effective Schools : Past, Present, and Future. Journal for Effective Schools. Vol 10 No.1. Idaho State University.

[16] Lesky. S, Stringfield. S, Teddlie. C, Kennedy. E, Schaffer. E, Chrispeels. J, Daly. A.J, \& McDonald. D (2005). Designing and Conducting a Gold Standard Effective Schools Study. Journal for Effective Schools. Vol 4 Number 1. Idaho State University.

[17] Litwin, G and Stringer, R (2001). Motivation and Organization Climate. Boston : Harvard University Press.

[18] Mills, J, Platts, K, Bourne, M, \& Richard, H (2002). Strategy and Performance : Competing Through Competence. Cambridge Univeristy Press.

[19] Purkey, S.C., \& Smith, M.S. (1983). Effective schools: a review. The Elementary School Journal, 83(4), 427-452.

[20] Reynolds, D. et. al. (1996)"School Effectiveness and School Improvement in the United Kingdom". School Effectiveness and School Improvement 7, 2, 133-158

[21] Reynolds, D. and Packer, A. (1992) School effectiveness and school improvement in the 1990s ${ }^{\text {ee }}$. In Reynolds, D. and Cuttance, P. (eds.) School Effectiveness: Research, Policy and Practice, London: Cassell.

[22] Rivai, F and Murni, S. (2009). Education Management. Jakarta : Rajawali Pers.

[23] Sallis, E. (1993). Total Quality management in Education. London : Kogan Page Educationanl Management Series.

[24] Sammons, P., Hilman, J., and Mortimore., P. Key Characteristic of Schools Effective : A Review of Schools Effectiveness Research. International Shools Effectiveness and Improvement Centre. London. 1995. pp. 10

[25] Schereens, J. (2000). Improving Schools Effective. UNESCO. Paris.

DOI: $10.9790 / 0837-2108104956 \quad$ www.iosrjournals.org
55 | Page 
[26] Sergiovanni, T.J (1990). Education Governance and Administration. $3^{\text {th }}$ Massasuchests : Publishing Group.

[27] Teddlei., C and Tashakkori, A. (2003). Handbook Mixed Methodes: in social \& Behavioral Research. Sage Publications. California

[28] Townsend, T. (1994). Effective Scholling for the Community. London and New York. Routledge.

[29] Willis D. Hawley and Donald L. Rolly. The Keys to Effective Schools: Educational Reform as Continuos Improvement. Corwin Press and NEA. California. 2007.pp 122-128

[30] Yukl, Garry (2002). Leadership and Organization. London : Prentice-Hall International. 